\title{
Investigating Innovation Capability and Organisational Performance in Service Firms
}

\author{
Jameel Al-kalouti ${ }^{1}$, Vikas Kumar ${ }^{1 * *}$, Niraj Kumar ${ }^{2}$, Jose Arturo Garza-Reyes ${ }^{3}$, Arvind Upadhyay ${ }^{4}$, and \\ Jeremy B Zwiegelaar ${ }^{5}$ \\ ${ }^{1}$ Bristol Business School, University of the West of England, UK \\ ${ }^{2}$ University of Liverpool Management School, UK \\ ${ }^{3}$ Centre for Supply Chain Improvement, The University of Derby, UK \\ ${ }^{4}$ Brighton Business School, University of Brighton, UK \\ ${ }^{5}$ School of Economics, Finance and Management, University of Bristol, UK \\ ** Communicating Author
}

Short Title: Innovation Capability and Organisational Performance

Main Conclusion: Our empirical investigation shows that in the service firm context innovation capability influences both the financial and non-financial performance.

\section{Key Points/Abstract}

Innovation is crucial for businesses to address key challenges anticipated by the changes in socioeconomic and environmental issues. Innovation capability is largely seen as a vital source for generating sustainable competitive advantage. The paper investigates the determinants of innovation capability, and their relationship with organisational performance in Jordanian banking sector. 
Strategic Change 2020; 29(1):103-113.

\section{Investigating Innovation Capability and Organisational Performance in Service Firms}

\section{Introduction}

Stakeholders' value creation has been the key driver for most business activities in today's economic environment. Huge investments have been made to develop sources for sustainable competitive advantage to improve overall business performance (Franco-Santos et al., 2012). In last few years, business environment is characterised as unstable and dynamic. Consequently, organisations need to continuously innovate and improve their performance to cope with the market uncertainty while simultaneously outperforming their rivals (Taticchi et al., 2010). Pandy (2005) argued that organisations do their best to find the optimal way to develop and promote their performance, use the best strategy that leads to goal achievement, and try to get the highest level of profit. In an unstable economic environment, it becomes necessary to continue improving the factors which can help to innovate. Given the nature of highly turbulent business environment, Melnyk et al. (2014) suggested the need for finding out-of-box innovative solutions. They emphasized that businesses need new approaches and models for innovation to compete and retain competitive advantage. A positive innovative climate is also vital for an organisations' success and performance improvement (Kohler et al., 2010). It can be argued that innovation has emerged as one of the mainstream research topic in last decade.

In $21^{\text {st }}$ century, Innovation is crucial for businesses to address key challenges anticipated by the changes in socioeconomic and environmental issues (de Medeiros et al., 2014, Pfeffer and Soutton, 2000). Jaskyte (2011) indicated that innovation also creates value for customer as it satisfies the needs of existing customers and market in creative ways. Many scholars have suggested that innovation leads to development of new product and new production techniques as well as opening of new markets, the use of new sources of supply and new forms of competition (Sledzik, 2013). Literature shows that innovation leads to change in organisations and also helps them to establish competitiveness. It is found that both the new innovative products and design help to maintain market share of the company and increase profits in those markets (Gaynor et al., 2001).

Over the years, a number of researchers have shown that innovation affects organisations' performance (Weiss and Anisimova, 2018; Alexander, 2015; Alegre, Sengupta, and Lapiedra, 2013; Laursen, and Salter, 2006; Hult et al., 2004; Johnston and Michiel, 1990; Saunila et al., 2014). Saunila et al. (2014) argues that innovation capabilities can lead to improved performance. Organisational performance can be improved and developed through innovation supported by various factors such as environment, organisational culture, and others (Saunila et al., 2014). Reflecting on that, several researchers focused on the effects of innovation on organisational performance (Bowen et al., 2010; Gunday et al., 2011; Jimenez and Sanz-Valle, 2011; Rheea et al. 2010; Upadhaya et al, 2014). Upadhaya et al. (2014) highlight that organisational performance and organisational effectiveness is interrelated. To illustrate more, studies by Mazzanti et al. (2006); Bowen et al. (2010); Gunday et al. (2011) and Saunila et al. (2014) show that performance and innovation are positively related. They also indicated that innovative firms have higher levels of productivity, firm's value, and growth than traditional non-innovating firms. Napier (2010) and Costello and Prohaska, (2013) highlight that newness and better performance as two essential concepts defining innovation. In global economy innovation is therefore seen as a driver of organisational growth and future success for businesses. In contrast, some researchers have shown that performance relationship with innovation is affected by other factors such as social, cultural, and environmental factors (Barnes and Hinton, 2012). Rasiah et al. (2016) provided an evolutionary perspective for innovation capabilities and suggested a measurement instrument using knowledge embodied in machinery, training, processes and products. The findings suggested that the innovation capability is linked with institutional support, and it influences the organisational performance in context of exports. A study by Gunday et al. (2011) suggests 
that practitioners and decision makers must consider factors associated with innovation to increase their operational performance.

The motivation for this research comes from the identified research gaps in dynamic and international operating organisations, identified by different researchers (such as, Barnes and Hinton (2012), Paranjape et al. (2006), Searcy (2012), Saunila et al., (2014) and others). Innovation though widely discussed in the manufacturing sector has now attracted attention in the service sector. However, Hipp and Grupp (2005) points out that the findings related to manufacturing sector cannot simply be replicated in the service sector. As a result, studies on innovation capability in context of service sector are scarce compared to the manufacturing sector (Hogan et al. 2011; Sigala and Kyriakidou, 2015). This study focusses on the banking sector for data collection in an emerging market. The paper aims to identify the key determinants of innovation capability and investigates its relationship with organisational performance in banking sector. Next section (section 2) reviews literature on innovation capability and organisational performance which is followed by the conceptual framework and research methodology in section 3. Section 4 presents the findings and discusses the findings in context of banking sector. The paper concludes in section 5 by highlighting the limitations and identifying the themes for future research.

\section{Background}

In general, innovation is considered as the main motive of economic growth in the global market. Potecea and Cebuc (2010) highlight that organisations and international businesses are focusing on innovation to compete and gain competitive edge. Innovation can take different forms in terms of a new product or service, a new process, or a new structure or a new operating system (Hult et al., 2004; Saunila et al., 2014). Many organisations adopt the idea of upgrading their competitive position and embrace innovation as it is a vital factor for survival and success (Baumol, 2002). Over the years many researchers have focused on the importance of innovation from the strategic prospective in building and sustaining competitive advantage and value creation (Ciabuschi et al., 2011; Franko, 1989). Previous literature discussed how organisations innovate, transfer innovation, and deal with innovation to gain competitive advantage and market share (Ciabuschi et al., 2011). This has been looked from the perspective of corporate context of innovations and the organisational structure, i.e. organisational internal and external capabilities (Ciabuschi et al., 2011; Hansen, 1999). On the other hand, Phene and Almeida (2008) points out that less attention has been paid on the outcome of the innovation process itself. Rogers (2002) described innovation as "an idea, practice or object that apparent as recent by people or the adoption unit". Nevertheless, the explanation of innovation in literature cannot be construed as it fails to give insights into different types of innovation and its relationship with sustainable competitive advantage. In fact, there are two key factors that define innovation: newness and better performance (Napier, 2010; Costello and Prohaska, 2013).

\subsection{Innovation capability and organisational performance}

Organisations are increasingly searching for new avenues to improve their market position and as a result, they develop their capability to continuously innovate. Innovation has emerged as a key source to secure competitive advantage in the market. Innovation enables firms to develop and implement more efficient and effective processes and strategies, resulting in developing innovative products. Bigliardi (2013) investigated the impact of innovative practices on the financial performance of SMEs, and argued that the financial performance of SMEs improved with an increase in the innovation level. Specifically, they highlighted the innovation practices developed in order to meet the customers' needs and to differentiate from the competitors resulting in improving the financial performance. Innovation capability affects performance of the firms. Innovation, knowledge sharing and firm performance are interrelated subjects that need to be further explored to understand their dynamics and implications. Similarly, Calantone et al. 
(2002) developed a framework to understand the relationship between learning orientation, innovation capability, and firm performance, and suggested that learning orientation is critical for innovation and firm performance. Learning orientation guides the strategy for resource generation and skills requirement for innovation and firm performance. Learning orientation of a firm can be strongly linked with the organisation culture. In this direction Baker and Sinkula (1999) highlighted the effect of market and learning orientation on firm performance. Saunila and Ukko (2012) reviewed past literature on innovation capability and performance, and developed a conceptual framework with five perspectives to measure the impact of innovation capability on business performance. Dadfar et al. (2013) also examined the organisational innovation capability, product platform development and performance relationships in pharmaceutical SMEs. They argued that firms tend to choose an imitative strategy in technology and product development, where the common pattern for technology sourcing was external. However, a combination of both internal and external sourcing for technology and product development is used by high performing firms. Sher and Yang (2005) also investigated the relationships between different dimensions of innovative capability and firm performance. The findings of the empirical study indicated that innovative capabilities have positive influence on performance as measured by Returns on Assets (ROA).

In this highly competitive business environment innovation could be recognised as a crucial factor for a successful business. In this line, Akman and Yilmaz (2008) examined the inter-relationships among market orientation, innovation strategy, innovative capability and innovation success for SMEs in developing countries, and discussed the mechanism for effective management of innovation in the software firms. Understanding the relationships among factors of innovation capability and firm performance may provide insight into how firms can improve their innovation capability to sustain their financial and non-financial performance. It is thus evident that past literature has studied the relationships between innovative practices and firm performance, but most of these studies are focussed on manufacturing industry, which provides the motivation for the current study. Vergori (2014) highlighted the recognition and importance of innovation in the service sector. However, the study also highlights that most research is mainly focused only on the quantitative nature of services such as productivity issues (Vergori, 2014). This study focusses on understanding the relationship between innovation capability and firm performance in service sector which has found limited discussion in literature. The first set of hypotheses that we aim to test are

\section{H1: Innovation capability positively influences financial performance}

\section{H2: Innovation capability positively influences non-financial performance}

Innovation capability is central not only for firm performance but also for the organisation's other activities. Lin (2007) examined the influence of different organisational factors and knowledge sharing processes on superior firm innovation capability. The paper argued that the organisational culture and the ability to share information and knowledge among the employees enable the firm to improve innovation capability. Panayides (2006) empirically examined the antecedents of innovation capability as well as its consequences. The study identified the relationship orientation as an antecedent to innovativeness that leads to higher levels of service quality and firm performance. The study further argued that innovativeness is an important factor for improving service quality, which as a result improves customer value and firm performance. However, Panayides (2006) also stressed that their research should be further extended to incorporate other industrial and cultural contexts. The positive link between organisational culture and innovation capability was also evident in the work of Naranjo-Valencia, Jiménez-Jiménez, and Sanz-Valle, (2016). Their study found organizational culture as a key determinant for firm innovation. However, they also pointed out that organisational culture can sometimes also act as a barrier against innovation. Where adhocracy culture positively influences on firm innovation, hierarchy culture negatively influences the firm innovation consistent with the findings in the literature. Various studies 
have explored the effect of culture on innovation and organisational performance. For instance, Leticia Santos-Vijande et al. (2013) investigated the impact of innovative culture on the performance of knowledge-intensive business services. They measured the performance in terms of the customer-related outcomes, and market and financial results relative to competition. They argued that organisations which promote innovative culture tend to perform better on competitive indicators. In this line, Tsai and Tsai (2010) and Saunila and Ukko (2014) investigated the innovation capability and business/firm performance relationships in different contexts. Hogan and Coote (2014) explored the positive linkages between the organisational culture, innovation and performance, a view consistent with other researchers. The discussion presented in this section leads to our third hypothesis.

\section{H3: Organisation culture positively influences innovation capability}

Highlighting the importance of knowledge transfer Cavusgil et al. (2003) discussed the tacit knowledge transfer affects the firm innovation capability based on the theory of knowledge. Moreover, based on the review of past literature, Lawson and Samson (2001) argued that innovation management can be viewed as one of the critical organisational capabilities responsible for competitive advantage. They argued that firms should invest and nurture this capability to execute effective innovation processes. As a result, this will lead to innovations in new product, services and processes, and superior business performance. In the high technology firm's context in China, Yang (2012) examined the antecedents of firm innovation capability and concluded that the firm's innovation capability does impact the long-term growth.

Romijn and Albaladejo (2002) investigated the determinants of innovation capability in small UK electronics and software firms and identified a number of internal and external factors responsible for improving the innovation capability of the firm. The importance of prior experience in the sector was found as one of the prominent internal factors in a scientific environment. A relationship between knowledge sharing, absorptive capacity, and innovation capability in Taiwan's knowledge-intensive industries was investigated by Liao et al. (2007). They argued that absorptive capacity behaves as an intervening factor between innovation capability and knowledge sharing. The empirical findings of Hong et al. (2004) also emphasized the importance of knowledge sharing in new product development. Liao, Fei and Chen (2007) argued that knowledge sharing is essential in developing knowledge capabilities which ultimately influences the firm's innovation capability. Yeşil et al. (2013) focused on the knowledge sharing process and its impact on innovation capability and performance of the firms. The study examined the influence of knowledge sharing process on innovation capability of the firms, and further linked it with the innovation performance of the firm. They argue that knowledge sharing has implication for innovation capability and innovation performance of the firms. Thus, these arguments lead to following hypothesis

\section{H4: Knowledge sharing positively influences innovation capability}

A number of research studies have shown the increasing importance of HR practices to the competitive advantages of firms in the rapidly changing knowledge-based economy (Chen and Huang, 2009; Delery and Roumpi, 2017). Past literature such as Sok and O'Cass (2011) focused on investigating the relationship between innovation resource - capability complementarity and innovation-based performance and reported that former drives the later. They asserted that this relationship could be further enhanced if the firms possess a superior learning capability, influenced by their culture. Such firms will be willing to question their operational processes and routines, and make improvements based on the feedback provided by customers on developing new products. Hewitt-Dundas (2006) attempted to identify the factors that constrain innovation. Their study showed that resource limitations have significant negative impact on the firm's innovation capability. Camelo-Ordaz et al. (2011) investigated the role of human resource management (HRM) practices in knowledge sharing and innovation through employees' affective commitment. Their findings show that HRM practices contribute to knowledge 
creation and innovation. And more recently, Donate, Peña, and Sanchez de Pablo (2016) in their study of the technological firms in Spain showed that collaborative HRM practices influence social capital, which, in turn, affect innovation capabilities of organisations. This leads to our next hypothesis.

\section{H5: Resource management positively influences innovation capability}

A number of studies (Wikström, 1995; Chen, Weng, and Huang, 2016; Cui and Wu, 2016) have reported the significance of customer engagement in establishing innovation capability, for example, Wikström (1995) highlighted that company-consumer interaction is becoming more frequent in a wide range of consumer industries and this interaction is enhancing the innovative capability of the producers. Sawhey et al. (2005) discussed the impact of internet on the process of collaborative innovation and suggested that firms can use this platform to engage customers in the collaborative innovation process for product development. The study by Lin et al. (2010) reasserted the role of customer engagement and relationship management as a key to increase their innovation capability. Based on the premise of the resource-based view (RBV) of the firm, Menguc et al. (2014) examined the effect of customer and supplier involvement in the design process and evaluating the performance of new products in Canadian high-tech companies. Findings of their study provided a strong support for the role of customer involvement in product design to improve new product performance under high incremental innovation capability. Recently, Chen et al. (2016) and Cui and $\mathrm{Wu}$ (2016) have stressed the importance of customer involvement in innovation process. Cui and $\mathrm{Wu}(2016)$ further argue that customer involvement as co-developers and co-innovators also results in improved product performance. These studies show that customer role cannot be ignored and must be prioritised along with other innovation capability drivers. This leads to our last hypotheses

\section{H6: Customer engagement significantly and positively affects innovation capability}

\subsection{Overview of Jordanian Banking sector}

Jordan is one of the emerging markets in the Middle East, attracting several international banks and foreign investments. Service sector and especially banking sector has been one of the key sectors participating in economic growth (Ongore and Kusa, 2013). The banking sector has always deemed to be one of the most vital sectors for the economy to be able to function. Recent financial crisis in mid-2007 had a severe impact on all sectors and banking sector was most hit by this crisis. Shah (2013) reports that a lot of industries went bankrupt after the last financial crisis in mid-2007 and many attributed this failure to lack of innovation capability or not measuring the process of innovation and innovation's outcome (Adams et al., 2006). Jordanian-banks were also severely affected during the recession. For example, Jordan Ahli Bank profits decreased by 46 percent, while Arab bank profits decreased by 17 percent after the crisis, as published in the annual reports of banks' annual in 2007 and 2008. A number of researchers have focused on performance measurement in banks such as Avkiran (2015), Barros, Managi, and Matousek (2012), and Ho and Zhu (2004). In particular, there are limited studies on the Jordanian banking sector (Tomar, and Bino, 2012; Almazari, 2012). This research therefore will concentrate on Jordanian banking sector as a focal point. The main driver of focusing on Jordanian banks is that there is a lack of studies addressing banking sector, especially in Jordan. Thus this study will address this research gap and further our understanding about innovation capability of Jordanian banking sector. As innovation capabilities are interrelated and can lead to improved performance (Saunila et al., 2014). Therefore, this research will also focus on examining the effect of the innovation capability on the organisational performance. 


\section{Conceptual Framework and Research_Methodology}

A theoretical framework based on the resource-based view was adopted to highlight the importance of resources and capabilities. The conceptual framework developed in this paper to understand the relationships between determinants of innovation capability and organisational performance is presented in Figure 1. From the review of literature presented earlier four determinants of innovation capability in a service organisation are identified as organisational culture (OC), knowledge sharing (KS), efficient resource management (RM), and customer engagement (CE). The organisational performance is measured in terms of both financial and non-financial performance. In the conceptual framework, organisational performance is the dependent variable, whereas the determinants of innovation capability are independent variables.

\section{[Insert Figure 1 here]}

Aiming to investigate the impact of innovation capability on performance this study sets out to adopt a quantitative approach. The choice of quantitative research method is purely driven by the explanatory nature of this study. The quantitative method of research is normally linked to the deductive approach aimed at testing theory and often follows a positivist philosophy. Since we intend to examine the relationship between the innovation capability factors and organisational performance, quantitative research methodology seems appropriate. In this study, empirical data was collected through the use of a survey questionnaire from Jordanian banks. The choice of Jordanian banking sector were made for two reasons; (1) the study aimed to contribute to the limited knowledge on the innovation capabilities in developing countries and Jordan being one of the fastest developing country suited the research requirement; and (2) one of the co-authors had worked in the Jordanian banking sector, thus has good connections which was needed for good survey response. So in summary the lack of studies on developing country context and access to the sector motivated the preferred option to conduct data collection from Jordan.

The survey questionnaire was uploaded and distributed through an online platform using Qualtrics. The data was collected over a period of 3 months between July 2015 and September 2015. Research questionnaire was distributed through personal networks involving bank's HR teams as one of the researchers had a good contact with bank professionals in the country. Professional websites such as LinkedIn was also used to circulate the survey. All banks in Jordan were considered for the sample of this study. Survey was circulated to around 300 respondents. In total 160 valid responses were collected representing a response rate of 53 percent. Several studies such as Cohen et al. (2007) and Watt et al. (2002) has suggested a response rate of 30 to 35 percent acceptable and according to these standards our sample size is considered to be good. Many studies have also indicated that achieving high responses is always challenging and have hence reported less than 25 percent response rate or lower survey responses (Belekoukias, Garza-Reyes and Kumar, 2014; Freise and Seuring, 2015). The ethical guidelines were strictly followed to maintain the confidentiality of the respondents. Statistical Package for Social Sciences (SPSS) was used to analyse the survey data. Next section elaborates the findings of the study.

\section{Findings and Discussion}

The findings of this study are based on 160 valid survey responses from different banks in the Jordan. All these responses were analysed through various statistical methods such as descriptive statistics, correlations and regressions. Majority of respondents were from large operating banks (around 79 percent) followed by from medium size banks (19 percent). The majority of the respondents were working at middle level (42 percent) whereas around 36 percent respondents were holding senior level positions (See Figure 2).

[Insert Figure 2 here] 
With regards to questions around innovation, results show that most banks consider launching new products and customer feedback as a way to continue to innovate. Most respondents ( 75 percent) also asserted that they link the success of launching new products with its financial returns and devote resources to develop new products and improve their services. In addition, the banks concentrate on the branding through being innovative. Most respondents ( 72 percent) also emphasized that their banks invest heavily in developing technological and other sources to improve performance. In addition, respondents agreed (63 percent) that their banks encourage the innovative culture between the employees and adopt a consistent innovative strategy. The evidence from the data therefore suggests that Jordanian banks consider innovation culture and strategy to support their innovation measurement through these means.

In order to investigate the linkages among the innovation capabilities indicators, innovation capability and performance measures, firstly correlation analysis was performed. The outcome of the correlation analysis is shown in Table 1. While investigating the linkage between the innovation capability indicators, innovation capability and organisational performance, the correlation analysis showed that there a positive and significant relationship exists between them, as they were significant at $p<0.01$ level. All the innovation capability indicators were moderately correlated $(0.3$ to 0.6$)$ with the organisational performance measures (both financial and non-financial performance). The indicators were also positively and significantly correlated with innovation capability suggesting that these indicators have significant influence on the innovation capability of organisations (see Table 1). The innovation capability was also positively and significantly correlated with the two performance measures financial performance $\left(.596^{* *}\right)$ and non-financial performance $\left(.597^{* *}\right)$. The findings support the argument that innovation capability does have a significant impact on the performance of the banks. These results also support discussions held in the previous literature (Cui and $\mathrm{Wu}, 2016$; Saunila et al. 2014; Taticchi et al., 2010,) and others that considers innovation capabilities as a dynamic balanced way in measuring performance.

\section{[Insert Table 1 here]}

It was also interesting to find significant correlation between the innovation capability indicators which indicates that an interrelationship exists between them. Findings shows that organisational culture has a strong correlation with knowledge sharing $(0.800)$ that was significant at $p<0.01$ level. This supports the existing arguments in the literature where culture is seen as a key factor for knowledge creation within the organisation that effectively contributes towards improving performance and stimulating creativity and innovation (Martins and Terblanche, 2003). This is also in line with the view of Martín-de Castro et al. (2013) who assert that intellectual and organisational knowledge assets as well as its ability to deploy these assets effectively are central for developing innovation capability. The significant correlation evident between the organisational culture and other measures of innovation capability is aligned with the literature that support the view that culture does impact a range of organisational processes and performance (Siehl, and Martin, 1988; Lee and Yu, 2004; Abu-Jarad, Yusof, and Nikbin, 2010). Thus, the findings support the notion that organisational culture plays a major role in innovation creation (Reigle, 2001). Customer engagement and resource management was also found be positively and significantly correlated (.602) which is aligned with the findings of Chen et al. (2017) which suggests that high commitment to HR practices improves customer service performance.

To further verify the impact of determinants on innovation capability, a regression analysis was performed. The regression analysis shows that altogether these determinants explain about 65 percent (Adjusted $\mathrm{R}^{2}$ value $=.651$ ) of the variance and co-efficient was also found to be significant (see Table 2).

[Insert Table 2 here]

To investigate the impact of innovation capability on organisational performance, firstly regression analysis was carried out with financial performance out which shows that it explains around 35 percent of the variance $\left(\right.$ Adj. $\mathrm{R}^{2}=.351$ ) (Table 3 ). Thereafter regression with non-financial performance was 
performed which was similar (Adj. $\left.\mathrm{R}^{2}=.352\right)$ (Table 4). This shows that innovation capability explains around 35 percent of variance in both performance measures significant at 1 percent level. We also tested the relationship between innovation capability indicators and organisational performance measures (see Table 5 and Table 6). The findings show that these indicators explain around 40 percent (Adj. $\mathrm{R}^{2}=.396$ ) of the variance in non-financial performance whereas only 28 percent of variance in the financial performance both significant at 1percent level.

[Insert Table 3 here]

[Insert Table 4 here]

[Insert Table 5 here]

[Insert Table 6 here]

The survey findings also show that more than 75 percent of the respondents agreed/ strongly agreed that all determinants (OC, RM, KS and CE) positively influence the development of innovation capability. This result supports the discussion held by Windrum and Garcia-Goni (2008). Rejeb et al. (2008) also argued that different determinants of innovation capability should be integrated, especially in the dynamic operating environment, in order to reach a reliable conclusion.

The findings provide the evidence for the understanding the impact of innovation capability on organisational performance in Jordanian banking sector. Findings show that the innovation capability studied in this research does affect both financial and non-financial performance positively. Moreover, it supports the discussion that considers measuring determinants of innovation capabilities to investigate the relationship with performance in more precise way. Our study also supports the arguments presented by Saunila et al. (2014) regarding innovation capability leading to improved performance.

\section{Conclusion, Limitations and Future research}

In the economic growth of a country banking sector plays a vital role. Innovation capability is largely seen as a crucial source for generating sustainable competitive advantage. This paper focusses on four determinants of innovation capability, organisational culture (OC), knowledge sharing (KS), resource management (RM), and effective customer engagement (CE) and establishes a positive relationship with organisational financial and non-financial performance. The findings indicate that all four determinants play a crucial role in driving innovation capability which in term influences the financial and nonfinancial performance of an organisation (see Table 7). The study provides a number of guidelines to both researchers and practitioners about the role that innovation plays in improving the performance of service organisations.

\section{[Insert Table 7 here]}

From theoretical perspective this study furthers our understanding of the relationships among innovation enabling factors and performance. The focus on four key innovation capability indicators that are applicable to service organisations and providing empirical evidence to their interrelationships adds to the limited existing literature in the area. The study also contributes to the limited knowledge on the innovation capabilities in developing countries by providing evidence from the Jordanian banking sector. Though the findings are based on the data from Jordanian sector, the findings are equally applicable to banking sector of many developing countries as most of them face similar challenges. It is also likely that findings from the banking sector could be also applicable to other service sector organisations, though this needs to be verified due to varying transactional nature of the service firms. From a managerial viewpoint this study identifies several factors that are essential in developing innovation capability. The study also discusses the implications of these factors in developing organisational strategies that encourage and 
foster financial and non-financial improvements. These findings are quite beneficial for managers on innovation pathway seeking to improve their organisational performance.

As is the case with most studies, this study has certain limitations. The findings of this study are based on limited survey responses (i.e. 160 responses) from Jordan banking sector. Although the limited responses in this study is better than many other past literature, for example, Upadhaya et al., (2014) - 58 responses, additional responses could help to further strengthen the findings and assist in generalisation across the sector. In addition, this study could also benefit from the support of qualitative data such as semistructured interviews to have an in-depth understanding of the motivations and challenges in developing innovation capability in service organisations.

Future research can adopt a mixed methods approach to triangulate the findings using both quantitative and qualitative methods. Future studies need to focus on collecting evidence from other service organisations in multiple countries to have a comprehensive understanding of innovation capabilities in variety of business settings. Particularly extending this study to compare developing and developed countries will be interesting to see. In addition, comparing findings of service sector with other sectors would also further our understanding of how these relationship dynamics changes across sectors. This study focused on four determinants of innovation capability therefore future studies can consider other dimensions at organisational and inter-organisational level. In addition, future studies can also use more robust statistical techniques to analyse the data such as structural equation modelling.

\section{References}

Abu-Jarad, I. Y., Yusof, N. A., and Nikbin, D., 2010, A review paper on organizational culture and organizational performance, International Journal of Business and Social Science, 1(3), 26-46

Adams, R., Bessant, J., and Phelps, R. 2006, Innovation management measurement: A review, International Journal of Management Reviews, 8(1), 21-47(2006)

Akroush M. N. 2008, Exploring the mediation effect of service quality implementation on the relationship between service quality and performance in the banking industry in Jordan, Global Business and Economics Review, 10 (1), 98-122

Alexander M. 2015, Innovations in inpatient flow and bed management, International Journal of Operations and Production Management, 35 (5), 751-781

Alegre, J., Sengupta, K., and Lapiedra, R. 2013, Knowledge management and innovation performance in a high-tech SMEs industry, International Small Business Journal, 31 (4), 454-470

Almazari A. A. 2012, Financial performance analysis of the Jordanian Arab bank by using the DuPont system of financial analysis, International Journal of Economics and Finance, 4 (4), 86

Avkiran N. 2015, A Multiple-Stakeholder Perspective on Bank Performance Measurement. Available at SSRN 2560159

Barnes, D. and Hinton, M. C. 2012, Reconceptualising e-business performance measurement using an innovation adoption framework, International Journal of Productivity and Performance Management, 61(5), 502-517

Barros C. P., Managi S., and Matousek R., 2012, The technical efficiency of the Japanese banks: nonradial directional performance measurement with undesirable output, Omega, 40 (1), 1-8

Belekoukias, I., Garza-Reyes, J. A., and Kumar, V. 2014, The impact of lean methods and tools on the operational performance of manufacturing organisations, International Journal of Production Research, 52 (18), 5346-5366.

Blome C., Paulraj A., Schuetz K., 2014, Supply chain collaboration and sustainability: a profile deviation analysis, International Journal of Operations and Production Management, 34 (5), 639 - 663 
Donate M. J., Peña I., and Sanchez de Pablo J. D. 2016, HRM practices for human and social capital development: effects on innovation capabilities, The International Journal of Human Resource Management, 27(9), 928-953

Bowen F. E., Rostami M., and Steel P. 2010, Timing is everything: A meta-analysis of the relationships between organizational performance and innovation, Journal of Business Research, 63(11), 11791185

Baumol W. J. 2002, Entrepreneurship, innovation and growth: The David-Goliath symbiosis, The Journal of Entrepreneurial Finance, 7 (2), 1-10

Ciabuschi F., Dellestrand H., and Martín O. M. 2011, Internal embeddedness, headquarters involvement, and innovation importance in multinational enterprises, Journal of Management Studies, 48 (7), $1612-1639$

Chen C. J., and Huang J. W. 2009, Strategic human resource practices and innovation performance-The mediating role of knowledge management capacity, Journal of Business Research, 62(1), 104114

Chen J. S., Weng H. H., and Huang C. L. 2016, A multilevel analysis of customer engagement, its antecedents, and the effects on service innovation, Total Quality Management and Business Excellence, 1-19

Cui A. S., and Wu F. 2016, Utilizing customer knowledge in innovation: antecedents and impact of customer involvement on new product performance, Journal of the Academy of Marketing Science, 44 (4), 516-538

Cohen, L., Manion, L., and Morrison, K. 2002, Research methods in education, 6th edition, Routledge, New York.

Costello T., and Prohaska B. 2013, Innovation, IT Professional, 15 (3), 62 - 64

De Medeiros J. F., Ribeiro J. L. D., and Cortimiglia M. N. 2014, Success factors for environmentally sustainable product innovation: a systematic literature review, Journal of Cleaner Production, 65, 76-86

Franco-Santos M., Lucianetti L., and Bourne M. 2012, Contemporary performance measurement systems: A review of their consequences and a framework for research, Management Accounting Research, 23 (2), 79-119

Franko L. G. 1989, Global corporate competition: Who's winning, who's losing, and the R\&D factor as one reason why, Strategic Management Journal, 10 (5), 449-474

Liao S. H., Fei W. C., and Chen C. C. 2007, Knowledge sharing, absorptive capacity, and innovation capability: an empirical study of Taiwan's knowledge-intensive industries, Journal of Information Science, 33(3), 340-359

Gaynor M., Bradner S., Iansiti M., and Kung H. T. 2001, The real options approach to standards for building network-based services, In Standardization and Innovation in Information Technology, $2^{\text {nd }}$ IEEE Conference, 217-228

Gunday G., Ulusoy G., Kilic K., and Alpkan L. 2011, Effects of innovation type on firm performance, International Journal of Production Economics, 133 (2), 662-676

Hansen M. T. 1999, The search-transfer problem: The role of weak ties in sharing knowledge across organization subunits, Administrative Science Quarterly, 44 (1), 82-111

Ho C. T., and Zhu D. S. 2004, Performance measurement of Taiwan's commercial banks, International Journal of Productivity and Performance Management, 53 (5), 425-434

Hult G. T. M., Hurley R. F., and Knight G. A. 2004, Innovativeness: Its antecedents and impact on business performance, Industrial Marketing Management, 33 (5), 429-438

Baker W. E., and Sinkula J. M. 1999, The synergistic effect of market orientation and learning orientation on organizational performance, Journal of Academic Marketing Science, 27, 411-427

Camelo-Ordaz C., Garcia-Cruz J., Sousa-Ginel E., and Valle-Cabrera R. 2011, The influence of human resource management on knowledge sharing and innovation in Spain: the mediating role of affective commitment, The International Journal of Human Resource Management, 22(07), 1442-1463

11 I $\mathrm{ag}$ e 
Calantone R. J., Cavusgil S. T., and Zhao Y. 2002, Learning orientation, firm innovation capability, and firm performance, Industrial Marketing Management, 31(6), 515-524

Freise, M. and Seuring, S. 2015. Social and environmental risk management in supply chains: a survey in the clothing industry. Logistics Research, 8(2), 1-12

Hogan S. J., Soutar G. N., McColl-Kennedy J. R., and Sweeney J. C. 2011, Reconceptualizing professional service firm innovation capability: Scale development, Industrial Marketing Management, 40 (8), 1264-1273

Lin H. F. 2007, Knowledge sharing and firm innovation capability: an empirical study, International Journal of Manpower, 28 (3/4), 315-332

Panayides P. 2006, Enhancing innovation capability through relationship management and implications for performance, European Journal of Innovation Management, 9 (4), 466-483

Tamer C. S., Calantone R. J., and Zhao Y. 2003, Tacit knowledge transfer and firm innovation capability, Journal of Business and Industrial Marketing, 18 (1), 6-21

Lawson B., and Samson D. 2001, Developing innovation capability in organisations: a dynamic capabilities approach, International Journal of Innovation Management, 5(3), 377-400

Leticia S. V. M., González-Mieres C., and Angel L.S.J. 2013, An assessment of innovativeness in KIBS: implications on KIBS'co-creation culture, innovation capability, and performance, Journal of Business and Industrial Marketing, 28 (2), 86-102

Lin R. J., Chen R. H., and Kuan-Shun Chiu K. 2010, Customer relationship management and innovation capability: an empirical study, Industrial Management and Data Systems, 110 (1), 111-133

Tsai M. T., and Tsai C. L. 2010, Innovation capability and performance in Taiwanese science parks: exploring the moderating effects of industrial clusters fabric, International Journal of Organizational Innovation, 2 (4), 80-103

Romijn H., and Albaladejo M. 2002, Determinants of innovation capability in small electronics and software firms in southeast England, Research Policy, 31 (7), 1053-1067

Saunila M., Pekkola S., and Ukko J. 2014, The relationship between innovation capability and performance: The moderating effect of measurement, International Journal of Productivity and Performance Management, 63 (2), 234-249

Saunila M., and Ukko J. 2013, Facilitating innovation capability through performance measurement: A study of Finnish SMEs, Management Research Review, 36(10), 991-1010

Liao S. H., Fei W. C., and Chen C. C. 2007, Knowledge sharing, absorptive capacity, and innovation capability: an empirical study of Taiwan's knowledge-intensive industries, Journal of Information Science, 33 (3), 340-359

Bigliardi B. 2013, The effect of innovation on financial performance: A research study involving SMEs, Innovation, 15 (2), 245-255

Ravichandran T., Lertwongsatien C., and Lertwongsatien C. 2005, Effect of information systems resources and capabilities on firm performance: A resource-based perspective, Journal of Management Information Systems, 21 (4), 237-276

Yeşil S., Koska A., and Büyükbeşe T. 2013, Knowledge sharing process, innovation capability and innovation performance: an empirical study, Procedia-Social and Behavioral Sciences, 75, 217 225

Sok P., and O'Cass A. 2011, Achieving superior innovation-based performance outcomes in SMEs through innovation resource-capability complementarity, Industrial Marketing Management, 40(8), 1285-1293

Dadfar H., Dahlgaard J. J., Brege S., and Alamirhoor A. 2013, Linkage between organisational innovation capability, product platform development and performance: The case of pharmaceutical small and medium enterprises in Iran, Total Quality Management and Business Excellence, 24 (7-8), 819834

Sigala M., and Kyriakidou O. 2015, Creativity and innovation in the service sector, The Service Industries Journal, 35 (6), 297-302 (2015) 
Saunila M., and Ukko J. 2012, A conceptual framework for the measurement of innovation capability and its effects, Baltic Journal of Management, 7 (4), 355-375 (2012)

Akman G., and Yilmaz C. 2008, Innovative capability, innovation strategy and market orientation: an empirical analysis in Turkish software industry, International Journal of Innovation Management, 12 (1), 69-111

Yang J. 2012, Innovation capability and corporate growth: An empirical investigation in China, Journal of Engineering and Technology Management, 29 (1), 34-46

Sher P. J., and Yang P. Y. 2005, The effects of innovative capabilities and R\&D clustering on firm performance: the evidence of Taiwan's semiconductor industry, Technovation, 25 (1), 33-43

Hipp C., and Grupp H. 2005, Innovation in the service sector: The demand for service-specific innovation measurement concepts and typologies, Research Policy, 34 (4), 517-535

Johnston D. A., and Michiel R. L. 1990, The diffusion of innovation within multi-unit firms, International Journal of Operations and Production Management, 10 (5), 15-24

Jaskyte K. 2011, Predictors of administrative and technological innovations in non-profit organizations, Public Administration Review, 71 (1), 77-86

Jimenez-Jimenez D., and Sanz-Valle R. 2011, Innovation, organizational learning, and performance, Journal of Business Research, 64(4), 408-417

Kohler T., Janßen C., Plath S. C., Reese J. P., Lay J., Steinhausen S., ... and Pfaff H. 2010, Communication, social capital and workplace health management as determinants of the innovative climate in German banks, International Journal of Public Health, 55 (6), 561-570

Laursen K., and Salter A. 2006, Open for innovation: the role of openness in explaining innovation performance among UK manufacturing firms, Strategic Management Journal, 27 (2), 131-150

Lee S. K. J., and Yu K. 2004, Corporate culture and organizational performance, Journal of Managerial Psychology, 19 (4), 340 - 359

Melnyk S. A., Bititci U., Platts K., Tobias J., and Andersen B. 2014, Is performance measurement and management fit for the future? Management Accounting Research, 25 (2), 173-186

Menguc B., Auh S., and Yannopoulos P. 2014, Customer and supplier involvement in design: The moderating role of incremental and radical innovation capability, Journal of Product Innovation Management, 31 (2), 313-328

Martins E. C., and Terblanche F. 2003, Building organisational culture that stimulates creativity and innovation, European Journal of Innovation Management, 6 (1), 64-74

Martín-de Castro G., Delgado-Verde M., Navas-López J. E., and Cruz-González J. 2013, The moderating role of innovation culture in the relationship between knowledge assets and product innovation, Technological Forecasting and Social Change, 80 (2), 351-363

Napier M., 2010, Charting new waters: Delivering innovative services for a different age, Perspectives in Public Health, 130 (3), 111-112.

Ongore V. O., and Kusa G. B. 2013, Determinants of financial performance of commercial banks in Kenya, International Journal of Economics and Financial Issues, 3 (1), 237-252

Pandy I. M. 2005, Balanced scorecard: myth and reality, Vikalpa, 30 (1), 51-66

Paranjape B., Rossiter M., and Pantano V., 2006, Performance measurement systems: successes, failures and future-a review, Measuring Business Excellence, 10 (3), 4-14

Pfeffer J., and Sutton R. I. 2000, The Knowing-Doing Gap: How Smart Companies Turn Knowledge into Action, Harvard Business School Press $1^{\text {st }}$ edition

Phene A., and Almeida P. 2008, Innovation in multinational subsidiaries: The role of knowledge assimilation and subsidiary capabilities, Journal of International Business Studies, 39 (5), 901919

Platts K.W. 1993, A Process Approach to Researching Manufacturing Strategy, International Journal of Operations and Production Management, 13 (8), 4 - 17

Hewitt-Dundas N. 2006, Resource and capability constraints to innovation in small and large plants, Small Business Economics, 26(3), 257-277 
Potecea V., and Cebuc G. 2010, Effects of economic crisis on the Romanian Economy, Romanian Economic and Business Review, 5 (2), 128-135

Rasiah R., Shahrivar R. B., and Yap X. S. 2016, Institutional support, innovation capabilities and exports: Evidence from the semiconductor industry in Taiwan. Technological Forecasting and Social Change, 109, 69-75

Reigle R.F. 2001, Measuring Organic and Mechanistic Cultures, Engineering Management Journal, 13 (4), 3-8

Rejeb H. B., Morel-Guimarães L., and Boly V. 2008, Measuring innovation best practices: Improvement of an innovation index integrating threshold and synergy effects, Technovation, 28 (12), 838-854

Hong P., Doll W.J., Nahm A.Y. and Li X., 2004, Knowledge sharing in integrated product development,

European, Journal of Innovation Management, 7, 102-12

Rogers E. M. 2002, Diffusion of preventive innovations, Addictive Behaviors, 27 (6), 989-993

Saunila M., Pekkola S., and Ukko J. 2014, The relationship between innovation capability and performance: The moderating effect of measurement, International Journal of Productivity and Performance Management, 63(2), 234-249

Scheer A. W., and Nüttgens M. 2000, ARIS architecture and reference models for business process management, In Business Process Management, Springer Berlin Heidelberg, 376-389

Searcy C. 2012, Corporate sustainability performance measurement systems: a review and research agenda, Journal of Business Ethics, 107 (3), 239-253

Shah, A 2013, Global Financial Crisis [Blog post].Retrieved from http://www.globalissues.org/article/768/global-financial-crisis.

Siehl C., and Martin J. 1988, Organizational culture: A key to financial performance?, Graduate School of Business, Stanford University

Delery J. E. and Roumpi D. 2017, Strategic human resource management, human capital and competitive advantage: is the field going in circles? Human Resource Management Journal, 27(1), 1-21

Śledzik K., 2013 Knowledge Based Economy in a Neo-Schumpeterian point of view Equilibrium, Quarterly Journal of Economics and Economic Policy, 8 (4), 67-77

Sawhney M., Verona G., and Prandelli E. 2005, Collaborating to create: The Internet as a platform for customer engagement in product innovation, Journal of Interactive Marketing, 19 (4), 4-17

Taticchi P., Tonelli F., and Cagnazzo L. 2010, Performance measurement and management: a literature review and a research agenda, Measuring Business Excellence, 14 (1), 4-18

Tomar S., and Bino A. 2012, Corporate Governance and Bank Performance: Evidence from Jordanian Banking Industry, Jordan Journal of Business Administration, 8 (2), 353-372

Upadhaya B., Munir R., and Blount Y. 2014, Association between performance measurement systems and organisational effectiveness, International Journal of Operations and Production Management, $34(7), 853-875$

Vergori A. S. 2014, Measuring innovation in services: the role of surveys, The Service Industries Journal, 34 (2), 145-161

Watt, S., Simpson, C., McKillop, C., and Nunn, V. 2002, Electronic course surveys: does automating feedback and reporting give better results? Assessment and Evaluation in Higher Education, 27 (4), 325-337.

Weiss, J. F., and Anisimova, T. 2018, The innovation and performance effects of well-designed environmental regulation: evidence from Sweden. Industry and Innovation, 1-34.

Windrum P., and Garcia-Goni M. 2008, A neo-Schumpeterian model of health services innovation, Research Policy, 37 (4), 649-672

Wikström S. 1996, The customer as co-producer, European Journal of Marketing, 30 (4), 6-19

Zhang M., Zhao X., Lyles M.A., Guo H. 2015, Absorptive capacity and mass customization capability, International Journal of Operations and Production Management, 35 (9), 1275 - 1294

Hogan S. J., and Coote L. V. 2014, Organizational culture, innovation, and performance: A test of Schein's model. Journal of Business Research, 67(8), 1609-1621 
Naranjo-Valencia J. C., Jiménez-Jiménez D., and Sanz-Valle R. 2016, Studying the links between organizational culture, innovation, and performance in Spanish companies. Revista Latinoamericana de Psicología, 48(1), 30-41 


\section{$\underline{\text { Tables }}$}

\begin{tabular}{|c|c|c|c|c|c|c|c|}
\hline \multicolumn{8}{|c|}{ Table 1: Correlation Analysis } \\
\hline & IC & FP & NFP & $\mathbf{R M}$ & OC & KS & $\mathbf{C E}$ \\
\hline IC & 1.000 & & & & & & \\
\hline FP & $.5966^{* * *}$ & 1.000 & & & & & \\
\hline NFP & $.597^{* *}$ & $.256^{* *}$ & 1.000 & & & & \\
\hline $\mathbf{R M}$ & $.772^{* * *}$ & $.519^{* * *}$ & $.574^{* *}$ & 1.000 & & & \\
\hline OC & $.629^{* *}$ & $.469^{* *}$ & $.436^{* *}$ & $.762^{* *}$ & 1.000 & & \\
\hline KS & $.522^{* * *}$ & $.397^{* * *}$ & $.344^{* *}$ & $.681^{* *}$ & $.800^{* *}$ & 1.000 & \\
\hline CE & $.550^{* * *}$ & $.432^{* * *}$ & $.509^{* *}$ & $.602^{* *}$ & $.671^{* *}$ & $.691^{* *}$ & 1.000 \\
\hline & \multicolumn{7}{|c|}{$\begin{array}{l}{ }^{* *} \text { Correlation is significant at the } 0.01 \text { level (2-tailed) } \\
\text { IC = Innovation Capability; FP= Financial Performance; NFP= Non-Financial Performance; RM= } \\
\text { Resource Management; OC = Organisational Culture; KD= Knowledge Sharing; CE = Customer } \\
\text { Engagement }\end{array}$} \\
\hline
\end{tabular}

Table 2: Regression Analysis (Innovation capability indicators)

\begin{tabular}{|l|l|l|l|l|}
\hline Model & R & R Square & Adjusted R Square & Std. Error of the Estimate \\
\hline 1 & $.814^{\mathrm{a}}$ & .662 & .651 & 2.64293 \\
\hline
\end{tabular}

a. Predictors: (Constant), OC, RM, KS and CE

Table 3: Regression Analysis (Innovation Capability and Financial Performance)

\begin{tabular}{|l|l|l|l|l|}
\hline & & & & \\
Model & $\mathrm{R}$ & R Square & Adjusted R Square & Std. Error of the Estimate \\
\hline 1 & $.596^{\mathrm{a}}$ & .355 & .351 & 1.72693 \\
\hline
\end{tabular}

a. Predictors: (Constant), Innovation Capability 
Table 4: Regression Analysis (Innovation Capability and Non-Financial Performance)

\begin{tabular}{|l|l|l|l|l|}
\hline Model & R & R Square & Adjusted R Square & Std. Error of the Estimate \\
\hline 1 & $.597^{\mathrm{a}}$ & .356 & .352 & 2.28905 \\
\hline
\end{tabular}

a. Predictors: (Constant): Innovation Capability

Table 5: Regression Analysis (Innovation Capability Indicators and Non-Financial Performance)

\begin{tabular}{|l|l|l|l|l|}
\hline & & & & \\
Model & $\mathrm{R}$ & R Square & Adjusted R Square & Std. Error of the Estimate \\
\hline 1 & $.645^{\mathrm{a}}$ & .415 & .396 & 2.20943 \\
\hline
\end{tabular}

a. Predictors: (Constant), OC, RM, KS and CE

Table 6: Regression Analysis (Innovation Capability Indicators and Financial Performance)

\begin{tabular}{|l|l|l|l|l|}
\hline Model & R & R Square & Adjusted R Square & Std. Error of the Estimate \\
\hline 1 & $.551^{\mathrm{a}}$ & .304 & .281 & 1.81674 \\
\hline
\end{tabular}

a. Predictors: (Constant), OC, RM, KS and CE

Table 7: Hypotheses Summary

\begin{tabular}{|l|l|}
\hline Hypotheses & Outcome \\
\hline H1: Innovation capability positively influences financial performance & Accepted \\
\hline H2: Innovation capability positively influences non-financial performance & Accepted \\
\hline H3: Organisation culture positively influences innovation capability & Accepted \\
\hline H4: Knowledge sharing positively influences innovation capability & Accepted \\
\hline H5: Resource management positively influences innovation capability & Accepted \\
\hline H6: Customer engagement significantly and positively affects innovation capability & Accepted \\
\hline
\end{tabular}




\section{Figures}

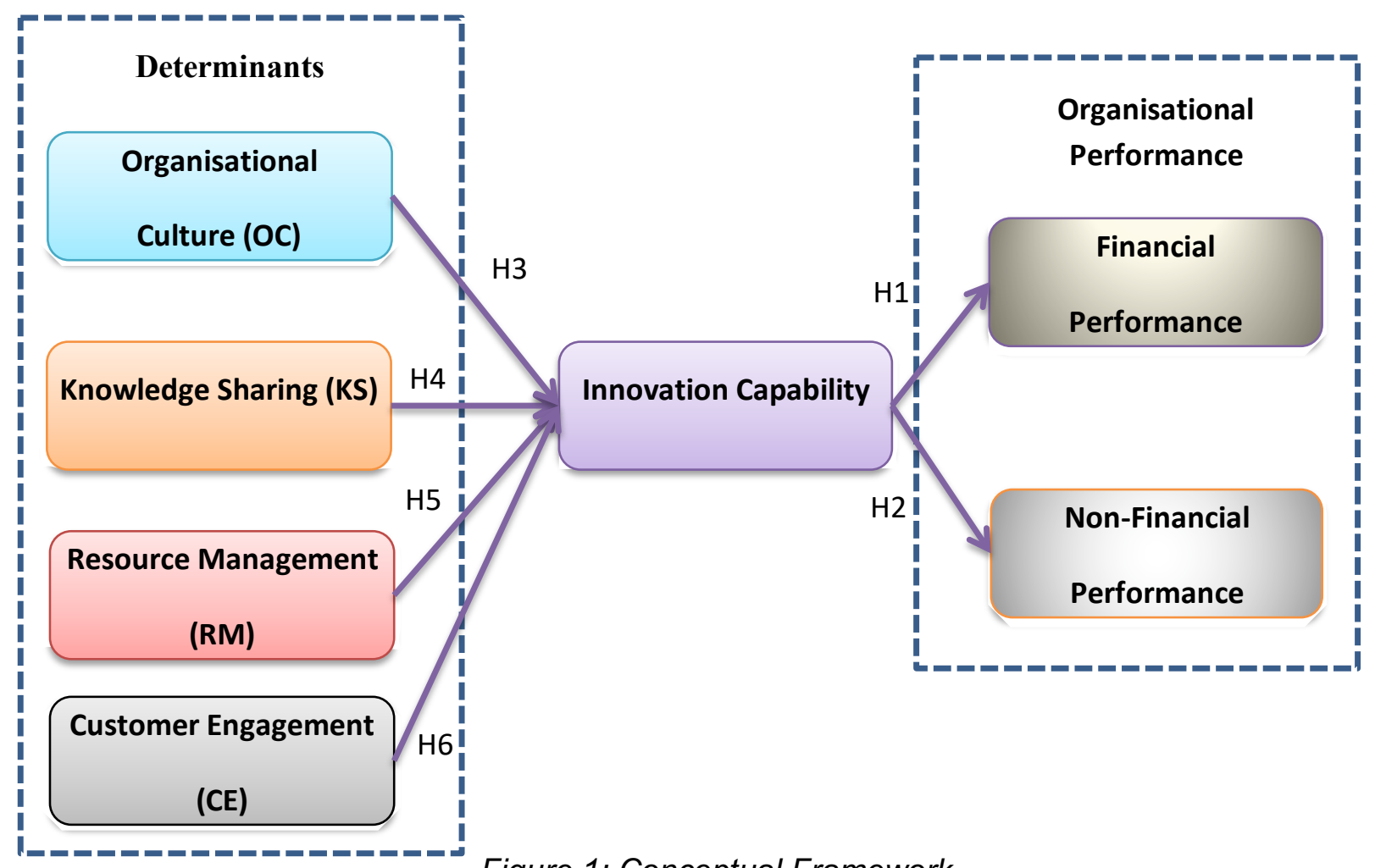

Figure 1: Conceptual Framework 


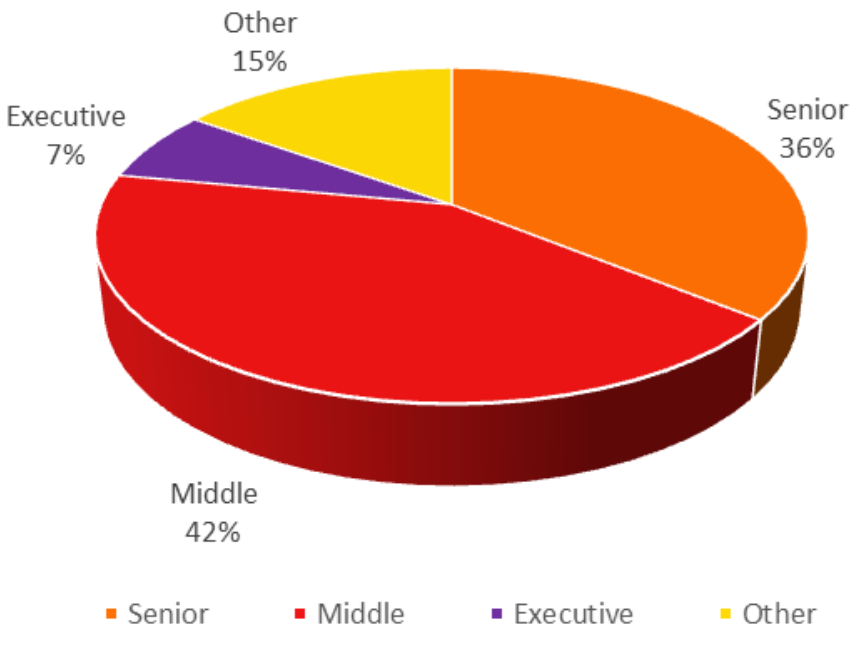

Figure 2: Participant Roles 